\title{
Parent Involvement Studies In Social Studies Course In Primary Education
}

\author{
Prof. Dr. Mehmet Gültekin \\ University of Anadolu, mgülteki@gmail.com \\ Arş. Gör. Zeynep Kılıç \\ University of Eskişehir Osmangazi, zeyno-dev@ hotmail.com
}

Primary education is a fundemental educational step where all individuals living in society can be acquired the basic knowledge, skills, behaviors and habits. These basic knowledge and skills, which the students should gain in primary education, are gained via primary (education) programs. In primary education programs, there are courses that causes the student to develop sophisticated. One of these courses is "Social Studies", which aims to cause the student gain basic life skills and positive personal qualifications. Social Studies is a course which takes the child's point of view and life as

basis, and provides the child to know herself/himself and her/his environment, and also it is a process in which basis for sophisticated and creative thinking, problem solving features are formed in harmony with the environment. In primary education, it is not possible to think Social Studies course separate from the parent. In Social Studies Course, one of the anticipated approaches to include the parent to education process is involvement of the parent. Parent involvement in education, which is defined as arranging studies/activities regular and systematically that anticipates family's participation to the education process, aims the child's participation to educationinstruction process and to provide consistency between the knowledge learned in the school and in the family. For this reason, family's participation is emphasised in basics os Social Studies' course. In this study, it was aimed to determine classroom teachers' opinions about parent involvement studies which are performed in Social Studies courses. Study was conducted upon opinions of classroom teachers' who worked in primary schools of Eskişehir. The study was conducted via qualitative method in survey model, and 35 classroom teachers were interviewed. Study data was analysed

via descriptive analysis technique. According to the results obtained in research findings, teachers has defined family participation in different forms such as parent's involvement to the child's education process, supporting the child, participating activities inside the school or classroom, in cooperation with school. It has been seen that, in Social Studies Course context, teachers organised different parent involvement's studies such as inviting parents to social activities and getting help in case of need, working into classroom activities, giving homeworks to students, which they may do with their parents, making meeting to inform parents, visiting parents and conducting a questionnaire. It has been seen that, teachers conduct parent's involvement's studies densely in the first class, and they conduct planning and informing parents while arranging parent involvement studies. It has been recognised that, teachers agree that parent involvement's studies have positive effects on teachers, students and parents.

* This research has been produced from the graduate thesis titled " Parent Involvement Studies In Social Studies Course In Prımary Educatıo" conducted at Anadolu University Educational Sciences Institute. 
Teachers stated that parent involvement's studies have impact on students' learning positively, increase the students' success and make them gain self-esteem, give opportunity to the parents to observe their children in the classroom, and simplify teachers' work. Among difficulties teachers encounter during parent involvement's studies, first problem is parents'reluctance to involve these kind of activities. In order to obtain desired success in parent involvement's studies, teachers suggest to give seminars to shareholders about parent involvement, to tell the importance of parent involvement in the parents' meetings, to cooperate with the school manager and the other administrators and to give place to family participation more.

Keywords: Social studies course, school-family cooperation, parent involvement.

\section{İlköğretimde Hayat Bilgisi Dersinde Aile Katılımı Çalışmaları*}

$\mathrm{Bu}$ araştırmanın amacı sınıf öğretmenlerinin Hayat Bilgisi dersinde gerçekleştirilen aile katılımı çalışmalarına yönelik görüşlerinin belirlenmesi amaçlanmıştır. Araştırma, Eskişehir il merkezindeki ilköğretim okullarında görev yapan sınıf öğretmenlerinin görüşlerine dayalı olarak gerçekleştirilmiştir. Tarama modelinde nitel yöntemle gerçekleştirilen, araştırma kapsamında 35 sınıf öğretmeni ile görüşme yapılmıştır. Araştırma verileri, betimsel analiz tekniği ile çözümlenmiştir. Araştırma bulgularından elde edilen sonuçlara göre öğretmenlerin aile katılımını; ailenin çocuğun eğitim sürecine katılması, ailenin çocuğuna destek olması, ailenin okulda ve sınıfta yapılan etkinliklere katılması, ailenin okul ile işbirliği içinde olması gibi değişik biçimlerde tanımladıkları görülmüștür. Öğretmenlerin Hayat Bilgisi dersi kapsamında aileleri okuldaki sosyal etkinliklere davet ettikleri ve gerektiğinde yardım aldıkları, aileleri sınıf etkinliklerine kattıkları, çocuğa ailesiyle birlikte yapacağı etkinlikler verdikleri, aileleri bilgilendirmek amacı ile toplantılar yaptıkları, aile ziyaretleri gerçekleştirdikleri ve ailelere anket uyguladıkları görülmüştür. Öğretmenlerin aile katılımı çalışmalarını yoğun olarak birinci sınıfta uyguladıkları ve aile katılımı çalışmaları düzenlerken planlama yaptıkları, aileleri bilgilendirdikleri görülmüştür. Öğretmenlerin aile katılımı çalışmalarının; öğretmen, öğrenci ve aile üzerinde olumlu etkileri olduğu konusunda görüş birliği içerisinde oldukları anlaşılmıştır. Öğretmenler, aile katılımı çalı̧̧malarının öğrencilerin öğrenmelerini olumlu yönde etkilediğgini, başarılarını, derse karşı ilgilerin ve öz güvenlerin arttırdığını, ailelere çocuklarını sınıf içinde gözlemleyebilme olană̆ verdiğini belirtmişlerdir. Ayrıca öğretmenler, aile katılımı çalışmalarının öğretmenlerin işlerini kolaylaştırdığını belirtmişlerdir.

Anahtar sözcükler: Hayat Bilgisi dersi, okul-aile işbirliği, aile katılımı

* Bu araştırma Anadolu Üniversitesi Eğitim Bilimleri Enstitüsü'nde yapılan "İlköğretimde Hayat Bilgisi Dersinde Aile Katılımı Çalışmaları" adlı yüksek lisans tezinden üretilmiştir. 
Hayat Bilgisi dersi, çocuğun ilköğretim okullarında karşılaştığı ilk derslerden birisidir. Hayat Bilgisi dersi farklı biçimlerde tanımlanmıștır. Çilenti'ye (1988) göre Hayat Bilgisi dersi; öğrencilerin kendisini ve çevresini tanımasının sağlandığı, çevresine uyum göstererek, çok yönlü ve yaratıcı düşünme, problem çözme gibi özelliklerinin temellerinin atıldığı bir derstir. Binbaşıŏlu (2003) ise Hayat Bilgisi dersini, çocuğa içinde bulunduğu toplumsal ve kültürel çevresini incelemesine olanak vererek çevre ile ilgili doğru bilgiler ve çevreye uyumda iyi alışkanlıklar ve gerekli beceriler kazandırmak amacıyla düzenlenen bir ders olarak tanımlamıştır.

Sönmez (2005, s.4), Hayat Bilgisini "Doğal ve toplumsal gerçekle kanıtlamaya dayalı bir bağ kurma süreci ve bu sürecin sonunda elde edilen dirik bilgiler" biçiminde tanımlamıştır. Sözer (1998) ise Hayat Bilgisinin, temel düzeyde bir bütün olarak doğal, toplumsal, sanatsal, çağdaş düşünce ve değerlerin tümünü içinde bulundurmasıyla ilgili olduğunu vurgulamıştır. Bu tanımlardan yola çıkarak Hayat Bilgisi dersinin çocuğu bilginin yanı sıra yaşamla ilgili temel becerileri kazandırdığı, çocuğun çevresiyle bilinçli bir biçimde uyum sağlamasını yardımcı olduğu ve çocuğun seviyesine uygun yaşam konuların yer aldığı bir ders olduğu söylenebilir (Deveci, 2008). Cumhuriyetten günümüze kadar tüm ilköğretim programlarında, Hayat Bilgisi öğretim programı yer almıştır. En son uygulanan Hayat Bilgisi öğretim programının temel vizyonu mutlu bireyler yetiştirmektir ve bu vizyon yerine getirmek için yapılandırmacı yaklaşım temel alınmıştır (Gültekin, 2004). Ayrıca Hayat Bilgisi öğretim programında; amaçlara ulaşma ve okulun etkililiğini arttırmada okul-aile işbirliği kapsamında aile katılımına büyük vurgu yapılmaktadır.

Aile katılımı, çocuğun yaşamında önemli bir yeri olan ailenin çocuğun eğitim-öğretim sürecine de katılımını ifade eder. Bu kapsamda aile katılımı; ailenin çocuğun akademik başarısı için desteğini (eg. Bloom, 1980), eğitim ve okul ile ilgili konularda ailenin çocukla iletişimini (eg.Christenson, ve diğerler, 1992, Walberg, 1986), ailenin okul etkinliklerine katılımını (e.g. Stevenson ve Baker, 1997), ailenin çocukları ile ilgili öğretmenle iletişimini (eg.Epstein, 1991) ve evde ailenin çocuklarını yönlendirmesini (eg. Keith, ve diğerleri, 1993, 1986, Marjoribanks, 1983) ifade etmektedir (Fan ve Chen, 2001, s.29). Ayrica Grolnick ve Slowiaezek (1994) aile katılımını, ailenin sahip olduğu kaynakları çocuğuna adaması olarak tanımlarken, Anderson ve Mike (2007) aile katılımını okulda çocuğun başarılı olması çocuğun eğitimini desteklemesi olarak tanımlamıştır. Epstein ise aile katılımını, annebabalık, iletişim, gönüllük, evde öğrenme, karar alma ve toplumla işbirliği biçiminde kategorilere ayırmıştır ve her kategoride ailenin gerçekleștireceği farklı sorumlulukları vardır (Epstein, 2001). Aile katılımı öğrenciye, öğretmene ve ailelere bazı yararları vardır. Aile katılımı ile öğrenci okulda başarılı olmak için çaba gösterir, ödevlerini yaparak okula gelir, okula yönelik olumlu tutum geliştirir, daha az devamsızlık yapar ve ailenin desteğinin hisseder ve sorumluluk duygusu geliştirir. Aile ise çocuğu tüm yönleriyle tanır, çocuğun ilgi ve yeteneklerinin farkında olur, çocuğun gelişimi hakkında bilgi sahibi olur, çocuğa bilinçli bir biçimde yardımcı olur. Öğretmen ise ailenin desteğini aldığı için daha verimli çalışır, aileler hakkında bilgi sahibi olur ( [National Parent Teacher Assocation] PTA, 1998;

Chen, 2008; Lim, 2003). Aile katılımının yararlarının yaşama geçirilmesi için öğretmenlerin aile katılımı kapsamında çeşitli derslerde farklı etkinlikler düzenlenebilir. Bu etkinlikler sınıf içinde olduğı gibi sınıf dışında da olabilir. Aile katılımı kapsamında; toplantılar, ev ziyaretleri, okul ziyaretleri, haber mektupları, duyuru panoları, kermesler, 


\section{Parent Involvement Studies In Social Studies Course In Primary Education}

sergi, gösterileri, sınıf gazeteleri ve bültenler, işbirliği defterleri gibi farklı etkinlikler yapılabilir (Cavkaytar, 2008; Stern, 2003; PFIE, Akt: Deveci ve Sözer, 2007; Temel, 2007). Hayat Bilgisi dersinin amaç ve kapsamı, çocuğun yaşadığı çevre ve yaşantısını oluşturduğu ve çocuğun bu yaşantı içerisinde aile de olduğu için Hayat Bilgisi dersinde aile katılımı etkinlikleri büyük önem taşımaktadır. Bu araştırma, aile katılımı çalışmaları konusunda ve Hayat Bilgisi dersinde aile katılımı çalışmalarına yönelik öğretmen görüşlerini belirleme gereksinimlerinden doğmuştur.

\section{Araştırmanın Amacı}

$\mathrm{Bu}$ araştırmanın amacı, ilköğretimde Hayat Bilgisi dersinde gerçekleştirilen aile katılımı konusunda sınıf öğretmenlerinin görüşlerinin belirlenmesidir.

\section{Yöntem}

Hayat Bilgisi dersinde gerçekleştirilen aile katılımı konusunda sınıf öğretmenlerinin görüşlerini belirlemeyi amaçlayan bu araştırma nitel yöntemle gerçekleştirilmiştir. Nitel araştırma, algıların ve olayların doğal ortamda gerçekçi ve bütüncül bir biçimde ortaya konmasına yönelik nitel bir sürecin izlendiği araştırmalar olarak tanımlanabilir. Nitel araştırmalar, gözlem, görüşme ve doküman analizi gibi nitel veri toplama yöntemlerinin kullanıldığı araştırmalardır (Yıldırım ve Şimşek, 2010).

\section{Katılımcilar}

$\mathrm{Bu}$ araştırmada, amaçlı örnekleme yöntemlerinden ölçüt örnekleme kullanılmıştır. Amaçlı örnekleme yöntemleri zengin bilgiye sahip olduğu düşünülen durumların derinlemesine çalışılmasına olanak vererek pek çok durumda, olgu ve olayların keşfedilmesinde ve açıklanmasında yararlı olmaktadır.

Ölçüt örneklemede ölçütler, araştırmacı tarafından oluşturulabilir ya da önceden hazırlanmış bir ölçüt listesi hazırlanabilir (Yıldırım ve Şimşek, 2010). Amaçlı örnekleme yöntemlerinden ölçüt örnekleme doğrultusunda öğretmenler için ak öğretmenlerin resmi ilköğretim okullarında sınıf öğretmeni olarak görev yapıyor olması ve bundan önceki yıllarda ilk üç sınıfı okutmuş ya da bu yıl üçüncü sınıf okutuyor olması, Hayat Bilgisi dersinde aile katılımı çalışmalarını uyguluyor ve araştırmaya gönüllü olarak katılıyor olmak üzere üç ölçüt belirlenmiştir. Bu kapsamda araştırmaya, Eskişehir il merkezinde bulunan farklı sosyo-ekonomik düzeydeki resmi ilköğretim okullarında görev yapan 35 sınıf öğretmeni katılmıştır.

\section{Veri Toplama Aracı}

Araştırmanın verileri, yarı yapılandırılmış görüşme yolu ile toplanmıştır. Görüşme, iki ya da daha fazla bireyin, belli amaçla, birinin diğerine doğrudan bilgi aktardığı, sözel ve sözel olmayan iletişim araç ve tekniklerini kullanarak, sohbet havasında yapılan etkileşimdir (Bogdan ve Biklen, 2006). Görüşme tekniği ile derinlemesine ve zengin bilgi edinilir (McMillian, 2004). Görüşme sorularının yer aldığı görüşme formunun geliştirilme aşamasında uzman görüşleri alınarak görüşme formunun araştırma amaçlarına uygun olmasına çalışılmıştır. Ayrıca, geliştirilen görüşme formunun ön deneme çalışması için 5 öğretmen ile görüşme gerçekleştirilmiştir. Ön deneme amac1yla gerçekleştirilen görüşmeler, araştırma kapsamı dışında tutulmuştur. Görüşme sonucunda 
ön görüşme yapılan öğretmenlerin her bir soruya verdiği yanıtlar çözümlenmiş ve görüşme sorularının anlaşılır ve açık olup olmadığı sınanmıştır. Çözümleme sonucunda anlaşılmayan bir soru olmadığı belirlenmiştir.

\section{Verilerin Cözümlenmesi}

Araştırma verilerinin çözümlenmesinde betimsel analiz tekniği kullanılmıştır. Araştırmada, her bir soruya verilen yanıtların dökümü yapılmıştır. Elde edilen bulgular sayısallaştırılmış, daha sonra yorumlanmıştır. Betimsel analiz; betimsel analiz için bir çerçeve oluşturma, tematik çerçeveye göre verilerin işlenmesi, bulguların tanımlanmasi, bulguların yorumlanması olmak üzere dört aşamada gerçekleştirilmektedir (Yıldırım ve Şimşek, 2010). Bu araştırmada, verilerin dökümünden sonra, veri analiz çerçevesi olarak görüşme sorularının kullanılmasına karar verilmiștir. Görüşme sorularına paralel olarak temalar olușturulmuştur. Her bir görüşme sorusuna ait öğretmenlerin yanıtları, oluşturulan temaların altına yazılıp görüşme kodlama anahtarı oluşturulmuştur. Görüşme kodlama anahtarında, görüşme yapılan öğretmenlerin tümünün görüşlerini yansıtan temaların ilgili sorular altında seçenek olarak sıralanmasından sonra yanıt seçeneklerinin güvenirliliğini belirlemek için üçer adet öğretmen görüşme dökümü yansız atama yöntemiyle seçilmiş̧ir. Seçilen üç adet öğretmen görüşme kodlama anahtarı çoğaltılarak alandan bir uzmana verilmiştir. Araştırmacı ve uzman, birbirlerinden bağımsız olarak görüsşme döküm formlarını ve görüşme kodlama anahtarının işaretlenmesi, görüşme yapılan öğretmen görüşüne uygun bulunan seçeneğin ilgili görüşme kodlama anahtarına işaretlenmesi biçiminde yapılmıştır. Araştırmacı ve uzmanın görüşme kodlama anahtarlarına yaptıkları işaretlemelerin tutarlılığını belirlemek amacıyla her sorunun yanıtı tek tek kontrol edilerek uzmanlar arası "Görüş birliği" ya da "Görüş Ayrıllı̆̆ı" biçiminde işaretlemeler yapılmıştır. Araştırmacı ve uzman ilgili soruda aynı yanıt seçeneğini işaretlemişse uzmanlar arası "Görüş Birliği" kabul edilmiş̧ir. Araştırmacı ve uzman ilgili soruda farklı yanıt seçenekleri işaretlemişlerse bu durum "Görüş Ayrılı̆̆ı" olarak kabul edilmiş ve araştırmacının işaretlediği seçenek temel alınmıştır. Geçerlik ve güvenirliği sağlamak için Miles ve Huberman'ın (1994) güvenirlik formülü P(Uzlaşma yüzdesi $)=\mathrm{Na}($ Görüş Birliği $) / \mathrm{Na}(\mathrm{Görüş} \mathrm{Birliği)}+\mathrm{Nd}($ Görüşs Ayrılığı)x100 kullanılarak hesaplanmıştır. Uzmanların ve araştırmacının değerlendirmeleri arasındaki uyumun \% 91 olduğu tespit edilmiştir. Araştırmanın tutarlılı̆ı katılımcı teyidi ile sağlanmıştır. Araştırmacının görüşmeleri bilgisayar ortamına aktararak elde ettiği ham veriler tekrar katılımcılara okutularak görüşme sırasında görüşlerin bu ham verilerdeki görüşler olduğuna ilişkin katılımcılardan teyit alınmıştır.

\section{Bulgular}

Yarı yapılandırılmış görüşmeler sırasında öğretmenlere birinci soru olarak "Aile katılımı deyince ne anlıyorsunuz?” sorusu yöneltilmiştir. Öğretmenlerin bu soruya verdikleri yanıtlar çizelge 1'de gösterilmiştir. 


\section{Sınıf Öğretmenlerin Aile Katılımı Tanımları}
a. Ailenin çocuğun eğitim sürecine katılması
b. Ailenin çocuğuna destek olmas1
c. Ailenin okul içinde ya da dışında yapılan etkinliklere katılması
d. Ailenin okul ile işbirliği içinde olması
e. Ailenin çocuğunu izlemesi
f. Ailenin çocuğu ile ilgilenmesi ve zaman geçirmesi
g. Ailenin okulda öğrenilen konuları yaşama geçirmesi
h. Ailenin eğitimin bir boyutunu oluşturması
i. Ailenin topluma hizmet etmesi

Çizelge 1. Sınıf Öğretmenlerin Aile Katılımı Tanımları

Çizelge 1'de görüldüğü gibi sınıf öğretmenleri aile katılımını, ailenin çocuğuna destek olması, ailenin okul içinde ya da dışında yapılan etkinliklere katılması, ailenin okul ile işbirliği içinde olması, ailenin çocuğunu izlemesi, ailenin çocuğu ile ilgilenmesi ve zaman geçirmesi, ailenin okulda öğrenilen konuları yaşama geçirmesi, ailenin eğitiminin bir boyutunu oluşturması ve ailenin topluma hizmet etmesi biçiminde tanımlamışlardır. Aile katılımı konusunda öğretmenlerden Ö1, "Zaten okuldaki eğitimöğretimin en büyük ăğrllğıın aile oluşturuyor. Yaptı̆̆ımı bütün çalışmalarda derslerde olsun, çocukların ev hayatlarında, çalışmalarında olsun aile katılıminın olması gerektiğini düşünüyorum. Ailenin pasif ya da aktif çocuğun eğitim hayatında olmasını diye açıklayabilirim. " biçiminde görüs bildirerek aile katılımını ailenin çocuğun eğitim sürecine katılması olarak tanımlamıştır. Öğretmenlerden Ö24 "Aile katılımı derken çalı̧̧malara ailenin katkısı, çocukları yönlendirmesi materyal sağlaması, kaynak sağlaması olarak anliyorum." biçiminde görüş bildirerek aile katılımını, ailenin çocuğun ödevlerini ya da araştırmalarını yaparken onu yönlendirmesi ya da materyal ve kaynak sağlayarak çocuğa destek olması biçiminde tanımlamıştır. Yine öğretmenlerden Ö23 "Ben aile katılımı deyince çocukların yaptığ etkinliklerde ailelerin birebir rol alması, üstlenmesi, çalısmalarda onlara katılması, sınıf ortamında bulunması veya okul dışı etkinliklerinde, gezilerde birlikte bunlarl anliyorum." biçiminde görüş bildirerek aile katılımını ailenin okul içi ve okul dışı etkinliklerine katılımı olarak ifade etmiş̧ir. Öğretmenlerden Ö22 “Aile katılımı, şimdi aile-öğretmen, öğretmen ve aile işbirliği olarak görüyorum. " biçiminde görüş bildirerek aile katılımını, ailenin okul ile işbirliği içinde olması ve öğretmenlerden Ö29 aile katılımını "Aile kattlımı deyince, ee ailenin sinıfta, sinıfa değil de öğrenciye evde yardımcı olması kontrol etmesi ve çocuğunu takip etmesini o şekilde anllyorum. " biçiminde tanımlayarak ailenin çocuğu izlemesi olarak 
belirtmişlerdir. Yine öğretmenlerden Ö7 "Ben, aile katıllmıyla öğrencinin-çocuğun ne diyeyim ailenin çocuğa daha fazla ilgilenmesi, onla beraber zaman geçirmesi anlamında değerlendiriyorum." biçiminde görüş bildirerek aile katılımını, ailenin çocuğu ile ilgilenmesi onunla birlikte zaman geçirmesi olarak tanımlamıştır. Öğretmenlerden Ö19 "Aile katılımı deyince ders konularının yaşantıya aktarımında ailenin rolü aklima geliyor. Yani işlenilen konuların yeri ve zamanı geldikçe aile tarafindan uygulanılması örneğin alış-verişe giderken yapılması gerekenleri gittiğinde çocuğuna örneklerle gösterilmesi ya da çevre temizliği konusunda kendisinin de örnek davranışlar sergilemesi herhangi bir çöpünü falan yere atmadan çöp kutusuna atması bunu da çocuğuna aktarabilmesini aile katılımı olarak adlandırabilir. " biçiminde görüş bildirerek aile katılımını, çocuğun okulda öğrendiklerini ailenin yaşama geçirmesi olarak tanımlamıştır. Öğretmenlerden, Ö25 "Eğitim üç boyutludur. Aile, okul ve çevre iliş̧kisi açısından ..." biçiminde görüs bildirerek aile katılımını eğitimin bir boyutu olarak tanımlarken, öğretmenlerden Ö14 "Hayat Bilgisi dersinde özellikle şimdiye kadar aile katılımı çalışmalarını biz topluma hizmet olarak adlandırıyoruz onu ailelerin de katıldığı tüm toplumu etkileyecek çalışmalar olarak düşünüp." biçiminde görüş bildirerek aile katılımını, ailenin topluma hizmet etmesi olarak tanımlamıştır. Kendileriyle görüşme yapılan öğretmenlerin çoğunluğu aile katılımını, ailenin çocuğun eğitim sürecine katılması, çocuğuna destek olması ve okul içinde ya da dışında yapılan etkinliklere katılımı olarak açıklamışlardır. Yine, öğretmenler aile katılımını, ailenin okul ile işbirliği içinde olması, çocuğunu izlemesi, çocuğu ile ilgilenmesi ve zaman geçirmesi, okulda öğrenilen konuları yaşama geçirmesi olarak düşünmektedirler. Ayrıca, öğretmenler aile katılımının eğitimin bir boyutu ve ailenin topluma hizmet etmesi olarak görmektedirler.

Araştırmaya katılan sınıf öğretmenlerine sorulan "Hayat Bilgisi dersi kapsamında aile katılımı ile ilgili ne tür çalışmalar yapıyorsunuz?" sorusuna verdikleri yanıtlar şekil 2 'de gösterilmiştir. Çizelge 2'de görüldüğü gibi, sınıf öğretmenleri, Hayat Bilgisi dersi kapsamında, aileleri okuldaki sosyal etkinliklere davet etme ve ailelerden gerektiğinde yardım alma, aileleri sınıf etkinliklerine katma, çocuğa ailesiyle birlikte yapacağı etkinlikler verme, aileleri bilgilendirmek amacı ile toplantılar yapma, aile ziyaretleri gerçekleştirme ve ailelere anket uygulama biçiminde etkinlikler gerçekleştirdiklerini belirtmişlerdir. 


\section{Parent Involvement Studies In Social Studies Course In Primary Education}

\section{Sınıf Öğretmenlerin Hayat Bilgisi Dersinde Gerçekleştirdikleri Aile Katılımı Etkinlikleri}
a. Aileleri okuldaki sosyal etkinliklere davet etme ve gerektiğinde yardım alma
b. Aileleri sinıf etkinliklerine katma
c. Çocuğa, ailesiyle birlikte yapacağı etkinlikler verme
d. Aileleri bilgilendirmek amac ile toplantılar yapma
e. Aile ziyaretleri gerçekleştirme
f. Ailelere anket uygulama

Çizelge 2. Sınıf Öğretmenlerin Hayat Bilgisi Dersinde Gerçekleştirdikleri Aile Katılımı
Etkinlikleri

Öğretmenlerden Ö16 “Velilerle şöyle biz sınıf gezisi yaptığımız zaman velilerimizle uygun olan velimiz bizimle gelebiliyorlar. Yll sonunda pikniklerimiz oluyor. Birlikte pikniklere katılabiliyoruz." biçiminde görüş bildirirken, öğretmenlerden Ö13 "23 Nisan etkinliklerinde sosyal faaliyetlerimizde, yıl sonu gösterileri yaptım, onlarda velilerin desteğini aldım ben. " biçiminde görüş bildirerek aile katılımı çalışması olarak, aileleri okuldaki sosyal etkinliklere davet ettiklerini ve gerektiğinde yardım aldıklarını belirtmişlerdir. Öğretmenlerden Ö26 "Birinci sınıftan bu yana verdiğimiz proje ve performans ödevlerini ailelerin katılımıyla sunduruyoruz. Yani çocuk çıkıyor, o göreve hem çocuk katıllyor hem aile katıllyor. Aile o proje ve performans görevlerini de gelip dinliyor. Hatta biz bunların fotoğrafinı çekiyoruz, internete veriyoruz. Burada aile katılımını sağlıyoruz." biçiminde görüş bildirerek aile katılımı çalışması olarak, aileleri sınıf etkinliklerine kattığını ifade etmiştir. Yine öğretmenlerden Ö11 "Mesela bir yumurta deneyimiz vard dişlere zarar veren içecekler. Suda bekletiyoruz kabuğunu işte kahvede bekletiyoruz, sirkede bekletiyoruz işste kolada bekletiyoruz. Bunu mesela deney olarak eve verdim. Dedim ki anneniz yardımcı olsun, size bardaklar hazırlasın içine içecekleri koysun bir yardımcı olsun, size bardaklar hazırlasın içine içecekleri koysun. Birkaç saat. Birkaç gün bekletin deney sonuçlarını bize yazın hatta pano da da sergiledik deney sonucunu aileyi kattık." biçiminde görüş bildirerek aile katılımı çalışmaları olarak, çocuklara ailesiyle birlikte yapacağı etkinlikler verdiğini belirtmiştir. Öğretmenlerden Ö12 "Önce yeni programı velilere tanıtmak amacılla toplantılar yaptım. İçeriğinin geçmiş yıllardaki yapılan programla karşılaştırılmasını ee ve bu yıl yapılacak olan Hayat Bilgisindeki ünitelerin temaların tanitılmasında onlara nasıl yardımcı olacakları açısından ipucu verdim." biçiminde görüş bildirerek aile katılımı çalışması olarak, aile ziyaretleri yaptığını ifade etmiştir. Öğretmenlerden Ö6 “Anketler, uyguluyoruz ailenin katılımı ile ilgili. Işte öğrenciyi tanıma, ögrenci üzerindeki işte 
ailenin etkisi, ayrica onlara rehberlikle ilgili ailenin işte annenin bir mektubudur babanın mektubudur buna benzer çalışmalarımız oluyor." biçiminde görüş bildirerek aile katılımı çalışması olarak, ailelere anket uyguladığını belirtmiştir. Kendileriyle görüşme yapılan öğretmenlerin çoğunluğu, düzenledikleri aile katılımı çalışmalarını; aileleri okuldaki sosyal etkinliklere davet etme ve gerektiğinde yardım alma, sınıf etkinliklerine katma, çocuğa ailesiyle birlikte yapacağı etkinlikler verme olarak açıklamışlardır. Yine, öğretmenler düzenledikleri aile katılımı çalışmalarını aileleri bilgilendirmek amacı ile toplantılar yapma, aile ziyaretleri gerçekleştirme ve ailelere anket uygulama biçiminde açıkladıkları görülmektedir.

Araştırmaya katılan sınıf öğretmenlerine sorulan "Hayat Bilgisi dersi kapsamında aile katılımı çalışmalarını nasıl uyguluyorsunuz?" sorusuna verdikleri yanıtlar Çizelge 3 'te gösterilmiştir.

Sınıf Öğretmenlerin Aile Katılımı Çalıșmalarını Uygulama Süreçleri

a. Planlama yapma, aileleri bilgilendirme, uygulama

b. Aileleri bilgilendirme, planlama yapma, gönüllü aileleri belirleme, iş bölümü yapma, uygulama

c. Yıllık planda aile katılımı çalışmalarını belirtme, resmi izin alma

d. Planlama yapma, velileri ikna etme süreci, uygulama ve değerlendirme aşaması

Çizelge 3. Sınıf Öğretmenlerin Aile Katılımı Çalışmalarını Uygulama Süreçleri Çizelge 3'te görüldüğü gibi aile katılımı çalışmalarını uygularken kendisi ile görüşülen öğretmenlerden, planlama yapma, velileri bilgilendirme, uygulama; aileleri bilgilendirme, planlama yapma, gönüllü aileleri belirleme, iş bölümü yapma, uygulama; yıllık planda aile katılımı çalışmalarını belirtme, resmi izin alma ve planlama yapma, velileri ikna etme süreci, uygulama ve değerlendirme biçiminde görüş bildirerek aile katılımı çalışmalarını planladıklarını belirtmişlerdir.

Öğretmenlerden Ö15 “Önce konunun ne olduğu eğer sınıfta aile katılımı yapacaksak konunun önce neler yapılması gerektiğini planını çıkarıyorum. Çă̆ıracă̆ım velinin ve ailelerin bundan haberdar olmasını sağlıyorum. Onun da tabii ki iznini alıyorum. Sınıfa geleceği günü belirliyorum. Sinıfta nasıl bir ortamda nasıl ders işleyeceği konusunda ya da katılımda bulunacă̆ konusunda bilgi alış-verişinde bulunuyorum. Sınıfta da birlikte bu katılımı gerçekleştiriyoruz." biçiminde görüş bildirerek aile katılımı çalışmalarını uygularken önce planlama yaptıklarını, aileleri ilgili konuda bilgilendirdiklerini ve uygulamayı gerçekleştirdiklerini belirtmişti. Yine öğretmenlerden Ö6 “Bunu ilk önce bir toplantı yapıp velilerle görüşüyoruz. Velilere bu işin yapılmasını yararlarını anlatıyoruz. Katılmayacak olanlar diye şey yapıyoruz ama genelde bunu çoğunluk kabul ediyor. Ondan sonra planlama ve iş bölümü yapıyoruz. İş bölümü yaptıktan sonra da bu işler yapılıyor." biçiminde görüş bildirerek aile katılımı çalışmalarını uygularken önce aileleri bilgilendirdiklerini, gönüllü aileleri belirlediklerini, planlama yaptıklarını, gönüllü aileleri belirlediklerini ve iş bölümü yaptıklarını sonra da uygulamayı gerçekleştirdiğini ifade etmiştir. 


\section{Parent Involvement Studies In Social Studies Course In Primary Education}

Öğretmenlerden Ö21 “Ylllık plana bunu ylllk planda bunu mutlaka aktif bir şekilde yazlyoruz. Öncellikle, yani şu ünite de işte gezi yapılacak, bu ünitede de mesela sağllk kurumlarında $n$ gezi yapılacak ya da hemen oraya bir parantez açıyoruz bir şey yaplyoruz ylllk plana yansittrken diyoruz ki, hasta olan bir arkadaşımızı ziyaret edeceğiz. Ee doğal olarak bunu yaptığımızda hasta olan arkadaş̧ hemen o ara bir önceki ya da bir sonraki ünitede o hani boşluğu doldurmak planımızda zaten var diğer gezilerde olsun işte bu meslekler çalışmalarında olsun küme gibi anlatımlarında olsun velileri sınıfa davet ederken o haftanın yoğunluğuna bakarak ya da o şeyin ünitenin önemine bakarak o mutlaka plana dahil edilir. Plan içerisinde zaten bize MEB'in bize gönderdiği kitaplarda buna benzer çalışmalar mutlaka oluyor. Bunu da napıyoruz biz biraz öncelikli tutmaya çalışlyoruz. Planlarda yer ediyoruz. Kendi çünkü çalışmalarımızda nasll ki bir geziyi düzenlerken oraya onu mutlaka yazarak yola çıkıyorsak resmi iznimizi öyle alıyorsak bu tür çalışmalarda da aynı çalışmayı yapıyoruz yani." biçiminde görüş bildirerek aile katılımı çalışmalarını yıllık planda belirttiğini ve resmi izin aldığını belirtmiştir. Öğretmenlerden Ö14 "Mutlaka planlamanin olmasinı savunan kişilerden biriyim ben. Planlama olmadı̆g zaman ne zaman ne yă̆acağınızı veli de onu anlayamaz. Öğrenciler de ona göre hazırlı̆̆ını yapamaz. İlk önce bu böyle bir çallş̧mayl vermeden önce hangi ayda hangi aşamalara gelmesi gerektiklerini eğer uzun vadeli bir çalışmaysa demin bahsettiğim gibi bir tasarrufsa konu veya okuma etkinliği ise ama kısa çallşmaların çocukların sunum yapacă̆ zamanlarda hangi aşamaların olacă̆ını, neler istediğimi belirten süresini belirten bir planlama mutlaka yapıyoruz. O ilk aşama planlama aşaması, ikinci aşamada velilerle birlikte tüm velileri toplayarak onlart ikna etme, sürecin içerisinde yer almaları için süreci onlara açıklama ve onlardan evet biz bu işte varız diye ikna sürecinin olmast. Bundan sonra uygulama aşaması geliyor. Uygulama aşamasında da her ay mesela ben çocuklara sorarım ne aşamadasını. Çünkü bazıları unutur, hiç başlamayan olabilir, bazı aile der ki bunu son bir hafta yapsam da olur kafalarda şey olur. Ama böyle sık sık uygulama aşamasında ne aşamada olduklarını sorduğumuz zaman kendilerine çeki düzen verme oluyor. Uygulama aşamasından sonra da belirlediğimiz mayls ayı oluyor genellikle bizim. Değerlendirme aşamamı var. Değerlendiriyoruz velilerle birlikte. Herkes sunumunu yapıyor. Neler yaptığını anlattyor. En son olarak da sonuç nedir, onu hep beraber değerlendirdikten sonra onu ben evlere, ödevlerin kenarlarına not düsserek geri dönüt olarak ulaşttrlyorum. Gayet güzel olduğunu düşünüyorum böyle aşamaları gerçekleştiriyoruz." biçiminde görüş̧ bildirerek aile katılımı çalışmalarını planlama, ikna etme, uygulama ve değerlendirme aşamaları ile uyguladığını belirtmiştir. Araştırmaya katılan sınıf öğretmenleri aile katılımı çalı̧̧malarını uygulamadan önce planlama, resmi izin alma gibi süreçleri izlediklerini ifade etmişlerdir.

Araştırmaya katılan sınıf öğretmenlerine sorulan "Aile katılımı çalışmalarının öğrencilerinizin öğrenmelerine ne gibi katkılar sağladığını düşünüyorsunuz?" sorusuna verdikleri yanıtlar çizelge 4 'te gösterilmiş̧tir. Çizelge 4 'te görüldüğü gibi aile katılımı çalışmalarının öğrencilerin öğrenmelerine katkıları konusunda kendisi ile görüşülen öğretmenler öğrenmelerini olumlu yönde etkilemesi, başarısının artması, derse karşı ilgilerinin artması, öz güveninin artması biçiminde görüş bildirmiş̧ir. Yine kendisiyle 
görüşülen öğretmenler, ailesiyle birlikte bir şeyler yapmaktan mutlu olması, ailelerinin yanında kendilerini daha güvende hissetmesi biçiminde görüş bildirmiştir. Yine kendisiyle görüşülen öğretmenler; öğrencilerde sorumluluk bilinci gelişmesi, sınıf içinde daha etkin olması, motivasyonunu arttırması, eğitime bakış açısını olumlu yönde etkilemesi, aile arası iletişimi arttırmast, sosyal becerilerini geliştirmesi, öz değerlendirme yapabilmesi, aile ve okul arasındaki ilişkiyi görmesini sağlamasi, ailesiyle kaliteli zaman geçirmesi, yaptı̆̆ ödevlerin niteliğinin artması, kaynaklara daha kolay ulaşması, okulda öğrendikleri ile evde öğrendikleri arasında paralellik olması, derse hazırlıklı gelmesi biçiminde görüş bildirmiştir.

Sınıf Öğretmenlerin Aile Katılımı Çalışmalarının Öğrenciye Katkılarına Yönelik Görüşleri
a. Öğrenmelerini olumlu yönde etkilemesi
b. Başarısının artması
c. Derse karşı ilgilerinin artması
d. Öz güvenin artmas1
e. Ailesiyle birlikte bir şeyler yapmaktan mutlu olması
f. Ailelerinin yanında kendilerini daha güvende hissetmesi
g. Öğrencilerde sorumluluk bilinci gelişmesi
h. Sınıf içinde daha etkin olması
i. Motivasyonunu arttırmas1
j. Eğitime bakış açısını olumlu yönde etkilemesi
k. Sosyal becerilerini geliştirmesi
1. Aile arası iletişimi arttırması
m. Öz değerlendirme yapabilmesi
n. Aile ve okul arasındaki ilişkiyi görmesini sağlaması
o. Ailesiyle kaliteli zaman geçirmesi
ö. Yaptığı ödevlerin niteliğinin artması

p. Kaynaklara daha kolay ulaşması

r. Öğrendikleri ile evde öğrendikleri arasında paralellik olması 
Çizelge 4. Sınıf Öğretmenlerin Aile Katılımı Çalışmalarının Öğrenciye Katkılarına Yönelik Görüşleri

Öğretmenlerden Ö11 “Şimdi hani denir ya gördüğ̈̈mü unutturup, işte işittiğimi unutup ama uyguladı̆̆ım şeyi unutmam diye annesiyle, babasıyla çalıştığı bir etkinliği çocuk gerçekten unutmuyor. ..... Çocuk görerek yaşayarak yaptığ için unutmuyor, kalıcı oluyor." ve öğretmenlerden Ö1 “"Bunu kendimden pay biçerek konuşursam ailenin arkasında olduğunu hissetmesi güvenin artması demek ee işte ailemde benim arkamda eğitimimi destekliyor diye düşünerek başarıyı arttırdığını düşünüyorum.” biçiminde görüş bildirerek aile katılımı çalışmalarının öğrencilerin öğrenmelerini olumlu yönde etkilediğini ve öğrencilerin başarılarını arttırdığını belirtmişlerdir. Ö21 "Şimdi aile katılımına destek veren velilerde o çocuklarda şunu gözlemliyoruz: benim annem babam bu olaya destek veriyor ögretmenimizin fikirlerine destek veriyor benim yapmaya çallş̧ı̆̆ım olaylara destek veriyor diyor ve o düşüncede de olduğu için derslerine mecburen önem gösteriyor." biçiminde görüş bildirerek aile katılımı çalışmalarının, öğrencilerin derslerine önem vererek derse karşı ilgilerini arttırdığını ifade etmiştir. Yine öğretmenlerden Ö6 "Bir defa öz güven kazandırlyor onlara da yani ailesinin yanında olması öğrenci için her dönemde önemlidir. Yani çocuktan çocuk için önemli bu öz güvenini gelişstiriyor. Yapamadiğg şeylerde mutlaka ailenin yardımının gerekli olduğunu biliyor. Öz güven yani en başta öz güven." biçiminde görüş bildirirken, öğretmenlerden Ö8 "Çocuk, ailesiyle birlikte bir şeyler yapmış olmaktan daha mutlu oluyor.", Ö4 "İşte davet ettiğim zaman anne-babalarını onlar daha kendilerini güvende hissediyorlar. Anne-babanın varlı̆̆ın arkada olduğu zaman kendilerini daha güvende hissediyorlar." ve Ö14 "Çocuk orda herhangi bir etkinlik yaparken ailesinin de yanında olduğunu görmek çocuğa çok güzel motive ediyor." biçiminde görüş̧ bildirerek aile katılımı çalışmalarının öğrencilere özgüven kazandırdığını, öğrencileri mutlu ettiğini, öğrencilerin kendilerini güvende hissettiğini ve motivasyonlarını arttırdığını belirtmişlerdir.

Yine öğretmenlerden Ö28 “Öğrencilerimize aile tarafindan çocuk kontrol edildiğini anlarsa takip edildiğini anlarsa verilen görevleri daha iyi daha düzenli bir şekilde yapıyor. Aile kontrolü olmadı̆̆ zaman çocuk ee çok fazla verilen görevleri yerine getirmiyor. $O$ nedenle bu konuda bayağ açısından da 'Benim ailem beni kontrol ediyor, sürekli beni denetliyor o nedenle ben görevimi tam olarak yerine getireyim.' diye sorumluluk duygusu da gelişiyor çocukta." biçiminde görüş bildirerek aile katılımı çalışmalarının, öğrencilerde sorumluluk bilinci geliştirdiğini belirtmiştir. Öğretmenlerden Ö33 "Kendilerine daha güzel ifade ettiklerini 
düşünüyorum. Çünkü yaşayarak öğreniyorlar birçok şeyi yaşayarak öğreniyorlar ve bunları da ders etkinliklerinde kendilerine ifade etmede kolaylı sağladığını düşünüyorum. Daha güzel ifade ediyorlar kendilerini artı kendilerine bunu yaşam biçimi olarak benimsiyorlar." ve Ö16 "Illetişim kurdukları için konuşarak iyi bir şey. İlişkiler çok sıcak bu da çok önemli bir şey, aile katılımı çalışmalarında aile ile çocuk iletişim kurduklarından aile ilişskilerini gelişiyor. Eğer biraz bilinçli anne-baba varsa aslında bu ödevleri yaparken çocuğunla günlük hayattaki ipuçların alabilir." biçiminde görüş bildirerek aile katılımı çalışmalarının, öğrencilerin sosyal becerilerini geliştirdiğini ve aile arası iletişimi arttırdığını belirtmişlerdir. Öğretmenlerden Ö3

"Kendi duygularını değerlendirmeyi biliyorlar. Karşısındaki anlayabiliyor. Ailenin okulun ne demek olduğunu arasındaki ilişkiyi kavramasını sağllyor, görüyor o açıdan." biçiminde görüş bildirerek aile katılımı çalışmalarının, öğrencilerin öz değerlendirme yapabilmelerini ve okul ve aile arasındaki ilişkiyi görmelerini sağladığını belirtirken, öğretmenlerden Ö7 “... performans çalışmalarımı var bizim bu kadar performans çallşmaların büyük çoğunluğu veya proje çallşmalarında öğrenci ee normalde bizim aile yapımızda çocuklar anne-babaları ile birlikte zaman geçirmezler. Birlikte bir şeyleri paylaşmazlar. Ee bu ders vasitaslyla bizim verdiğimiz bunlardan hangisinden alırsan al aile katılımı çalışmalarının vasitasıyla çocuk ee annesiyle-babasiyla mutlu olabileceği yani hani diyorlar ya yani iyi dakikaları, iyi saatler yani değerlendirilmiş güzel dakikaları, saatleri geçirerek paylaşabilecekleri bir şeyler meydana

çıkarıyorlar." biçiminde görüş bildirerek aile katılımı çalışmalarının, öğrencilerin ailesiyle birlikte kaliteli zaman geçirmelerini sağladığını belirtmiş̧tir. Öğretmenlerden Ö9 "Yapttklarl ödevler daha tatmin edici oluyor çünkü aksayan yönleri onlar tamamliyorlar. Arkadaşlar içinde mesela çocuk ödevini tam ve güzel yapamazsa sinıfta sunum ortamında sunmayı bile istemiyorlar. Ĕger ödevi güzel olmamışsa ben sunmayacağım diyor parmak kaldırmayı tercih etmiyor mesela. Ama öyle bir çalı̧̧ma yapmış güzel konu alınca sunmakta istekli oluyor ve güzel de çalışma oluyor." biçiminde görüş bildirerek aile katılımı çalışmalarının, öğrencilerin yaptığı ödevlerin niteliğinin artmasını sağladığını belirtirken, öğretmenlerden Ö24 "Aile katılımı çalışmaları kaynaklara ulaşmada daha bilinçli davrandıklarını internet kullanımında özellikle çok işe yartyor." biçiminde görüş bildirerek aile katılımı çalışmalarının, öğrencilere kaynaklara ulaşmada bilinçli davranmalarını sağladığını belirtmiştir. Öğretmenlerden Ö18 "Ya bir kere aile katılımı derken çalışma sadece okulla sinırlı olmuyor. Okulda belli bir süre durabiliyorsunuz. Çocuk hayatını büyük kısmını evde yaşlyor. Ya ne bileyim en basitinden ödevini falan yaparken bir yanlış yaptiğında aile bunu destekliyorsa yanlışını daha çabuk düzeltir doğal olarak hani çocuk hatasını anlar bir iki üçten sonra daha dikkatli olmaya başlar. Ama öbür türlü mesela hiç desteklemezse aile, yanlıs şekilde öğreniyor sirf okulda düzeltildiğinde şey yapıyor ya da ne bileyim aileler evde davranışlarına, hareketlerine dikkat ederlerse yine çocuğun davranışlarında faydası olacağını düşünüyorum. Yani bir yerde mesela öğretmenin 


\section{$47 \quad$ Parent Involvement Studies In Social Studies Course In Primary Education}

yanlış dediğine aile yanlış demiyorsa onda da bir fesatllk oluşuyor. Çocuğun burada da kafası karışıyor öğretmenin dediğini bazen çok dikkate almayabiliyor. Bakiyor, hayatın çoğunluğu evinde geçiyor yapılan doğrudur herhalde diye düşünebiliyor." biçiminde görüş bildirerek aile katılımı çalı̧̧malarının öğrencilerin okulda öğrendikleri ile evde öğrendikleri arasında paralellik olmasını sağladığını belirtmiş̧tir. Öğretmenlerden Ö27

"Dediğim gibi derse hazırlanma, konuyu pekişstirme, ee evde davranışı o evde konuyu davranış hale getirme konusunda çok fazla yardımcı oluyor. Derse hazırlkkl geliyorlar. Böyle olunca ögrenciler, dersler daha rahat işleniyor." biçiminde görüş bildirerek aile katılımı çalışmaları öğrencilerin derse hazırlıklı gelmelerini sağladığını belirtmiştir. Araştırmaya katılan sınıf öğretmenlerine sorulan "Aile katılımı çalı̧̧malarının size öğretmen olarak ne gibi katkılar sağladığını düşünüyorsunuz?” sorusuna verdikleri yanıtlar çizelge 5 'te gösterilmiştir. Çizelge 5 'te görüldüğü gibi, aile katılımı çalışmaların öğretmenlere katkıları konusunda kendisi ile görüşülen öğretmenler işlerini kolaylaştırması, öğrencinin ailesini tanıması, öğrencisini daha iyi tanıması, ögretmen ile aile arasında iletişsimi geliştirmesi, ögrretmenler için ders işlemenin daha kolay olmasl, mutlu olması ve öğretmene destek sağlaması biçiminde görüş bildirmiştir. Yine, kendisiyle görüşülen öğretmenler öğretmen-aile-okul işbirliğini güçlendirmesi ve çalışmalarının denetlenmesinin sağlanması biçiminde görüş bildirmiştir.

\section{Sınıf Öğretmenlerin Aile Katılımı Çalışmalarının Kendilerine Katkılarına Yönelik Görüssleri}
a. İşlerini kolaylaştırması
b. Öğrencinin ailesini tanıması
c. Öğrencisini daha iyi tanıması
d. Öğretmen ile aile arasında iletişimi geliştirme
e. Mutlu olmas1
f. Öğretmene destek sağlaması
g. Öğretmen-aile-okul işbirliğini güçlendirmesi
h. Çalışmalarının denetlenmesini sağlaması

Çizelge 5. Sınıf Öğretmenlerin Aile Katılımı Çalışmalarının Kendilerine Katkılarına Yönelik Görüşleri

Öğretmenlerden Ö19 “Tabii bizim işimizi kolaylaştırtyor. Çünkü aile desteği olduğunda çocuktaki olumsuzlukları birlikte görerek hareket edersek çözüm yolları da üretmiş oluyor. Kolaylaştırıyor yani işsimizi bir bakıma." Ö4 "Aileleri daha yakından tanıyorsunuz, çocuklar nasıl sosyal yapıdan geliyor onları izleyebiliyorsunuz ve çocuğa 
nasıl yaklaşmamız gerektiği hakkında size ipuçları veriyor." ve Ö22 "Öğretmen olarak bana çocukları daha iyi tanımamı sağllyor." biçiminde görüş bildirerek aile katılımı çalışmaların öğretmenlerin işlerini kolaylaştırdığını, aileleri ve çocukları daha iyi tanıdıklarını belirtmişlerdir. Öğretmenlerden Ö1 "Yani destektir. Yani tek başına bu işin dönmediği belli. Öğrenci ile öğretmen arasinda geçen bir şey değil eğitim-öğretim, aileyi yanımıza almamı gerekiyor. Ne kadar destek ve yardım alırsak her konuda bir iyileşme sağlayacağımızı düşünüyorum." biçiminde görüş bildirerek aile katılımı çalışmaların öğretmenlere destek sağladığını belirtirken, öğretmenlerden Ö11 “

Öğretmenlere, okul-aile, ögrretmen-veli işbirliğini güçlendiriyor." biçiminde görüş̧ bildirerek aile katılımı çalışmalarının okul-aile-öğretmen işbirliğini güçlendirdiğini belirtmiştir. Ayrıca öğretmenlerden Ö34 "Öğretmenlerin çalışmalarını bir nevi veli ögretmen işbirliği içerisinde denetlenmiş oluyor bir üçgen yani oto kontrol sistemini otomatikman sağlamış oluyoruz." biçiminde görüş̧ bildirerek aile katılımı çalışmalarının öğretmenlerin çalışmalarını denetleme olanağı verdiğini belirtmiştir. Yine öğretmenlerden Ö14 "Ben, bir ögretmen olarak velilerimin yanında olması her zaman, velilerden güç almak her zaman benim ilk felsefem olmuştur. Beni mutlu ediyor. Olayın içinde yer alması, ..... ailenin çocuğu için bir şeyler yaptığını hissettirebilmek ögretmen olarak bizleri mutlu ediyor." biçiminde görüş bildirerek aile katılımı çalışmalarının öğretmeni mutlu ettiğini belirtmiştir.

\section{Sınıf Öğretmenlerin Aile Katılımı Çalışmalarının Ailelere Yönelik Katkılarına} Yönelik Görüşleri
a. Çocuklarını sınıf içinde gözlemleyebilmesi
b. Mutlu olmas 1
c. Okulda/sınıfta yapılan çalışmalara yönelik bilgi sahibi olması
d. Çocuklarını tanıması
e. Çocuğun eğitimi konusunda bilinçlenmesi
f. Çocuklarının eğitim-öğretimindeki önemlerini anlaması
g. Aileler arası iletişim kurulması
h. Çocukları ile zaman geçirmesi
i. Sinav kaygisından kurtulması
j. Öğrenmede bireysel farklılıkları fark etme 
k. Yeni programlar hakkında bilgi sahibi olması

1. Öğretmenle iletişim halinde olması

m. Öğretmene olumlu tutum geliştirmesi

n. Öğretmeni değerlendirebilmesi

Çizelge 6. Sınıf Öğretmenlerin Aile Katıılımı Çalışmalarının Ailelere Yönelik Katkılarına Yönelik Görüşleri

Yapılan görüşmeler sırasında öğretmenlere sorulan "Aile Katılımı Çalışmalarının Ailelere Ne Gibi Katkılar Sağladığını Düşünüyorsunuz?” sorusu yöneltilmiş̧ir. Öğretmenlerin bu soruya verdikleri yanıtlar Çizelge 6'da gösterilmiştir.

Çizelge 6'da görüldüğü gibi, aile katılımı çalışmaların ailelere katkıları konusunda kendisi ile görüşülen öğretmenler, "Çocuklarını slnıf içinde gözlemleyebilmesi", "Mutlu olması", "Okulda/sinıfta yapılan çalışmalar hakkinda bilgi sahibi olması", "Çocuklarını tanıması", "Çocuğun eğitimi konusunda bilinçlenmesi” biçiminde görüş bildirmişlerdir. Yine öğretmenler, "Çocuklarının eğitim-öğretimindeki önemlerini anlaması", "Aileler arası iletişim kurması", "Çocukları ile zaman geçirmesi", "Sinav kaygısından kurtulması", "Öğrenmede bireysel farklllkları fark etme" , "Yeni programlar hakkinda bilgi sahibi olması", "Öğretmenle iletişim halinde olması", "Ögrretmene olumlu tutum geliştirmesi" ve "Öğretmeni değerlendirebilmesi" biçiminde görüş bildirmişlerdir. Öğretmenlerden Ö29 "Kendi çocuğunu gözlemleyebiliyor sinıf ortamında aile. Yani diğer arkadaşlarıyla ilişskilerini gözlemliyor veya başka bir yetişkinle ilişsisini, ders ortamındaki tutumunu gözlemliyor. Buna göre de kendi çocuğundaki eksiklikleri görüp bunu düzeltme yoluna da gidebiliyor.”, Ö1 "Bence veliler mutlu oluyordur. Ĕğitim-öğretim içerisinde olduğunu bilmek, çocuğunun yanında olduğunu bilmek, ögretmenle omuz omuza olduğınu bilmek, yanında olduğunu bilmek, işe yaradı̆̆ını bilmek çocuğuna fayda sağladı̆̆ını bilmek mutluluk verir yani.", Ö31 "Ailenin de okulda ne yapıldı̆̆ından haberi oluyor. Onlarda neyin eksik kaldığınl, çocuğuna ne şekilde yardım edebileceğini, çocuğun eksiğini görebiliyor. Ailenin de okulda yapılan etkinliklerden, bilgilerden bilgisi oluyor." ve Ö19 “Aile çocuğunu tanıma firsatı buluyor her şeyden önce. Çocuğunun olumlu, olumsuz, eksik yönlerini ya da hani başarıları konusunda çocuğunu daha iyi tanımaya tanıma imkânı buluyor. Çocuğunu tanıdı̆̆ iç̧in anlatmaya kalktı̆̆ımızda çocuğunu tanıyan aile daha bilinçli yaklaşıyor. Bence aile çocuğuna hangi konuda daha yetenekli olup olmadığına bilirse ek desteklerle sağlayabilir. Yani çocuğun sportif yönü olabilir, müzik alanında olabilir başka başka etkinliklere katılımı yönünden. " aile katılımı çalışmaların, ailelere 
çocuklarını sınıf ortamında gözleme olanağı verdiğini, aileleri eğitim sürecine katıldığı için mutlu ettiğini, okulda/sınıfta yapılanlar hakkında bilgi sahibi olduğunu ve çocuklarını daha iyi tanıma olanağı verdiğini belirtmişlerdir. Öğretmenlerden Ö27

"Çocuğunun ne öğrendiğini çocuğunun hangi konularda yetiştirildiğini biliyor ve hangi konularda çocuğuna yardımcı olabileceğini fikrine varıyor. Artı o anlamda da rehberliği gelişiyor. Neler yapılabileceği nasıl daha yardımcı olabileceği konusunda kendisini gelişstiriyor." biçiminde görüş bildirirken Öğretmenlerden Ö2 "Bir kere, 'Ben okula gönderiyorum. Her şeyi okulda öğrenip geliyor, gelmesi lazım.' düşüncesinden kurtuluyor veli. Ya okulda öğretmenin 30 öğrenciye birden inemeyeceğini, evde mutlaka, bireysel kendisinin uğraşması gerektiğini, takip̧̧isi olmasını gerektiğini, eksiklerini fark etmesi gerektiğini anlyyor.”, Ö6 "Onlar arasinda da aileler arasindaki iletişimi, birbirlerini tanımalarını, onların iyi ilişskiler kurmaların sağllyor.”, Ö20 "Yeni programlar hakkında bilgi sahibi oluyorlar. Onlar da günün çağlarına göre kendi ögrrencilik dönemlerindeki öğretim sistemlerine göre bi de yeni yöntem ve teknikler hakkında bilgi sahibi oluyor. Önceden onların zamanında biliyorsunuz ögretmen merkezli bir öğretim vardl. Şimdi öğrenci merkezli olduğu için burada kendileri de bocalyyorlar. Programin felsefesi ve genel görüşü hakkinda bilgi sahibi oluyorlar." ve Ö5 "Veliler de biraz daha bilinçleniyor. Buraya geliş-gidiş̧leri bile değişiyor. Nasıl davranması gerektiklerini öğreniyorlar yani buraya bazen terlikle bile gelen veliler oluyor. Okula, kuruma geliyorlar. Yani pijama ile terlikle gelinmesi uygun değil. Ona göre davranarak daha bilgili daha iyi yaklaşımlar sunuyorlar." biçiminde görüş bildirerek, aile katılımı çalışmalarının, ailelerin çocuğun eğitimi konusunda bilinçlenmesini, aileler arası iletişim kurulmasını, aileler arası iletişim kurulmasını sağladığını ve ailelerin çocukların eğitimi konusunda kendilerinin önemli olduklarını hissettiklerini belirtmişlerdir.

Öğretmenlerden Ö23 "Onlarla birebir iletişim kurmaları olumlu yönden etkiliyor diye düşünüyorum. Başka, yine en azından günün bir saati olsa bile onlarla birlikte vakit geçirmiş oluyorlar, onları daha iyi anlayabileceklerini düşü̈üyorum. Ben aile katılıminın önemli olduğınu düşünüyorum." biçiminde görüş bildirerek aile katılımı çalı̧̧malarının, ailelere çocuklarıyla zaman geçirme olanağı verdiğini belirtmişlerdir. Öğretmenlerden Ö30 "Sinlf ortamında var olduğu zaman bir bireyin farkl öğrenme zamanları olduğunu, hereksin farklı ögrendiği o yüzden hani gereksiz psikolojik travmalar yaratmamak için gereksiz basklar içerisinde olmamak gerektiğini ben algıladıklarını düşünüyorum sinıf ortamında. Yani aslında hani onlar empoze edilen sınav kaygısı gibi durumları ortadan kaldırdığın düşünüyorum ben." biçiminde görüş bildirerek aile katılımı çalışmalarının, ailelere sınav kaygısından kurtulma ve öğrenmede bireysel farklılıkları fark etme olanağını verdiğini belirtmiştir. Ö26, "Bir kere ögretmenle iletiş̧imleri, diyaloglar oluyor. Öğretmenle diyalogları olduğu için çocukların durumlarını daha iyi takip edebiliyorlar, rahatlyorlar." biçiminde görüş bildirirken Ö35 “... öğretmeni de eleştirebilme şansları da yüksek oluyor ki ben de 


\section{Parent Involvement Studies In Social Studies Course In Primary Education}

bundan yanayım. Veliye, beni rahatlikla eleștirebilme firsatı veriyor." ve Ö32 "Öğretmenine güven saygı kazanabilir çünkü çocuğuna derste nasıl davrandığını öğretmenin görür ve ona göre de ögretmenine karşı güveni de artar saygısl da artar." aile katılımı çalışmaların, ailelere öğretmenle iletişim kurmalarına, öğretmene yönelik olumlu tutum geliştirdiğini ve ailelere öğretmeni değerlendirebilme olanağ verdiğini belirtmişlerdir. Yapılan görüşmeler sırasında öğretmenlere sorulan "Aile Katılımı Çalışmalarında Ne Tür Zorluklarla Karşılaşıyorsunuz?" sorusu yöneltilmiştir. Öğretmenlerin bu soruya verdikleri yanttlar Çizelge 7'de gösterilmiştir.

\section{Sınıf Öğretmenlerin Aile Katılımı Çalışmalarında Karşılaşılan Zorluklara} Yönelik Görüşleri
a. Ailelerin aile katılımı çalışmalarına katılmak istememesi
b. Öğrencilere verilen ödevlerin aileler tarafından yapılması
c. Ailelerin, çalışmaları nedeniyle aile katılımı çalı̧̧malarına zaman ayıramaması
d. Ailelerin ekonomik bakımdan olanaklarının yetersiz olması
e. Okulun fiziki ortamının uygun olmaması
f. Ailelerin öğretmene olumsuz tutumu
g. Öğrencinin sınıfta ailesini görünce olumsuz davranışlar sergilemesi
h. Anne-babanın eğitim düzeylerinin düşük olması
i. Ailelerin aşırı ilgili olması
j. Aile katılımı çalışmalarının öğretmeni yorması
k. Ailelerin çocuklarının okuldaki öğrenmelerini evde desteklememesi
1. Öğrenci sayısının fazla olması
m. Ailenin sorumluluğu öğretmene brrakması
n. Parçalanmış ailelerin olması

Çizelge 7'te görüldüğü gibi aile katılımı çalışmalarında karşılaşılan zorluklar konusunda, kendisi ile görüşülen öğretmenler; "Ailelerin aile katılımı çalışmalarına 
katılmak istememesi”, "Öğrencilere verilen ödevlerin aileler tarafından yapılması", "Ailelerin, çalışmaları nedeniyle aile katılımı çalışmalarına zaman ayıramaması", "Ailelerin ekonomik bakımdan olanakların yetersiz olması", "Okulun fiziki ortamının uygun olmaması" biçiminde görüş belirtmiştir. Yine, kendisiyle görüşülen öğretmenler, "Ailelerin öğretmene yönelik olumsuz tutumu", "Öğrencinin sınıfta ailesini görünce olumsuz davranışlar sergilemesi”, "Anne-babanın eğitim düzeylerinin düşük olması", "Ailelerin aşırı ilgili olması", Aile katılımı çalışmalarının öğretmeni yorması", "Ailelerin çocuklarının okuldaki öğrenmelerine evde desteklememesi", "Öğrenci sayısının fazla olması", "Ailelerin sorumluluğu öğretmene bırakması”" ve "Parçalanmış ailelerin olması" biçiminde aile katılımı çalışmalarında karşılaşılan zorluklara ilişkin görüş bildirmişlerdir.

Öğretmenlerden Ö10 “Bizimle irtibat kurmak istemeyen aileler oluyor. Çocuğunu kabul etmeyen aileler oluyor. Yani benim çocuğum o şekilde değil diye onlarla sorun yaşlyoruz. Görüşmek istemiyor. Davet ediyoruz, çocuğun hakkında konuşacağız ya da çocuğun ile şöyle bir çalışma yapacağız senin katılımını istiyoruz, yok hayır itiraz ediyor. Katıllım göstermiyor.", Ö24 "İ̧ste karşılaş̧tı̆̆ımız en büyük zorluk çalışmanın velinin ailenin çocuğun yerine alıp yapması karşılaştı̆̆ımı en büyük zorluk o." ve "Şimdi çalışan ailelere ulaşmak biraz zor oluyor açıkçası. Zamanlama konusunda bazen sıkıntılarımız olmuş olabiliyor. Yani o an için mesela iş yerinden izin alamayabiliyor o konuda." biçiminde görüş bildirerek aile katılımı çalışmalarında karşılaşılan zorluk olarak ailelerin bu tür çalışmalara katılmak istemediklerini, ödevleri ailelerin yapması ve ailelerin çalışmaları nedeniyle bu tür etkinliklere zaman ayıramadıklarını belirtmişlerdir. Öğretmenlerden Ö18 "Daha çok kendi hayat şartlarına şey yapmışlar, kaptırmışlar. Çocuklara tamam ne diyorlar mesela otur çalış. Yanında oturtup çallş̧ırmak başka bi de şey de var. Biraz tabii ekonomik şeylerde etkiliyor. Mesela benim geçen sene çalış̧tı̆ım köyde internet daha geçen sene gelmişti ve her bir veli bilgisayar alabilecek durumda değil mesela günümüzde şuan internet çok yaygin bir bilgiye en çok onla ulaşılabiliyor. O tarz imkânları kusitllydı. Araştır dediğim zaman ansiklopedi araştırma şeyleri. Bi de ben de birinci, ikinci sinflar vardl gene bende. Anca belli başll kaynak da azdı bundan kaynaklanıyor. Velinin ekonomik durumu Tabii bunda çok büyük etkisi var. Kimisi mesela çok iyi durumda olan mesela birisi çocuğa her türlü imkân sunabiliyor. Ama maddi sıkıntı yaşayan ya da geliri çok değilse almıyor." biçiminde görüş bildirerek aile katılımı çalışmalarında karşılaşılan zorluk olarak ailelerin ekonomik bakımdan olanaklarının yetersiz olduğunu belirtmiştir. Öğretmenlerden Ö30 "Ya bizim o tür konulardaki zorluklarımız aslında ailelerle ilgili falan değil. Daha çok okullarımızın fiziki yapılarından kaynaklanan olumsuzluklardan dolayl yaşıyoruz.", Ö1 "Olumsuz şeyler yaşanabilir, yanlı̧̧ değerlendirme yapılabilir bu kişsiye göre kişilere göre değişebilir. Olumsuz özelliklere sahip bir veli yanllş değerlendirmeler yapabiliyor. Niye beni değil onu seçti veya beni niye seçmedi bana az görev verdi gibi olumsuz düşüncelere sahip olabiliyor. Buna halk dilinde dedikodu 
diyoruz. Böyle olumsuzluklar yaşanabiliyor.”, Ö29 “Ama en önemli negatifliği bizim için daha rahat yani sinıf kuralların bile çiğneyebiliyor ailesinden destek almış oluyor annesinin yanında. Normalde sinıf ortaminda yapmadı̆̆ davranışl annesinden babasindan destek alarak daha rahat bir şekilde yapabiliyor. Oluyor. Bunun olumsuzluklarını yaşadık yani.", Ö2 "Biraz değil aslında tek zorluk eee bu okulun çevresinde anne, babanın ailenin biraz daha eğitimin az olması." ve Ö16 "İ̧̧⿻ zorluklar oluyor. Nasıl zorluk şimdi veli bilgili her şeyi ile ilgili yani o zaman sinfftan şöyle bir örnek vereyim: her şeyi ile ilgilenir. Mesela çok yaramaz, çok üzücü, kırıcl, kırdı ama hiçbir kere veliyi ben çağırmamışımdır yani sizin oğlunuz şu arkadaşını rahatsı etmiş diye. Şöyle bir şey oldu bu oğlumu başka sinıftan biri rahatsız ettiği zaman beni hemen müdüre şikayete geldi. Şimdi arada farkl anlayabiliyor musun? Aslında kendi oğlundaki bazı davranışları düzeltmeye çalışlyoruz. Yani ben bunu düzeltirken evet hoca hanım işiniz zor ben çocuğumu biliyorum bu iş zordur bunu el birliği ile yapalım dememişstir. Ama bin şikayetle gelip masum çocuğu şikayet etmiştir. Ilginin böylesi çok zor bir şeydir. Yani fazla ilginin zorluğu bence." biçiminde görüş bildirerek aile katılımı çalışmalarında karşılaşılan zorluk olarak okulların fiziki ortamının uygun olmaması, ailelerin öğretmene olumsuz tutum içinde olmasını, öğrencilerin sınıfta ailelerin yanında olumsuz davranışlar sergilemesi, anne-babanın eğitim düzeyinin düşük olması ve ailelerin aşırı ilgisi olduğunu belirtmişlerdir.

Öğretmenlerden Ö14 "Bunun yanında zorlukları da var tabii ki. Bir planlama yapmak ögretmenin bir şekilde fedakârlı yapmasını gerektiriyor. Hazırlık yapmak bunun sonuçların değerlendirmek, geri velilere vermek şu çalışmadan şu sonuçları elde ettik diye bahsetmek bunlar öğretmeni yorucu şeyler." , Ö20 "Karşılaşllan zorluklar şu, aileler bildiğgi kendi doğrular yönünde çocuğu yönlendiriyor birincisi. Bir yandan çocuk arada kallyor. Yani kendi doğru bildiği ile annesinin doğru bildiği arasında sıkışıp arada kalyyor ve ögretmenin gözünün içine baklyor. Öğretmenim şimdi ben bunu yaptım dercesine. Bu sikintılarla da karşılaş̧ıoruz.”, Ö26 “Öğrenci saylları problem, öğrenci sayılarının sürekli artmasl bu tür etkinliklerin tam olarak yerine ulaşmasını engelliyor." , Ö27 "Eğitim, kültür seviyesi çok farkl, sosyo -ekonomik durumu çok farkl çevremizdeki ailelerin. Herkes eğitime ayn ölļüde bakmıyor, eğitim konusunda fikirleri farkl tamamen okula, ögretmene birakan veliler var öyle olunca da onlardan, o çocuklardan çok fazla gelişme sağlayamıyoruz." ve Ö34 "Parçalanmış ailelerde zorluk çekiyoruz. En büyük sıkıntımız bizim parçalanmış ailelerde sıkıntı yaşıyoruz ayrıca ekonomik güçlüğ̈̈ olan ailelerde slkıntı yaşıyoruz." a ile katılımı çalışmalarında karşılaşılan zorluk olarak aile katılımı çalışmalarının öğretmeni yorması ailelerin çocuklarının okuldaki öğrenmelerini evde desteklememesi, olarak öğrenci sayısının fazla olması, sorumluluğu öğretmene bırakması olduğunu ve parçalanmış ailelerin olmasını belirtmişlerdir. 
Görüşmeler sırasında öğretmenlere dokuzuncu soru olarak "Aile Katılımı Çalışmalarında istenilen Başarının Elde Edilmesi İçin Neler Yapılmalıdır?" sorusu yöneltilmiştir. Öğretmenlerin bu soruya verdikleri yanıtlar çizelge 8 'te gösterilmiştir.

\section{Sınıf Öğretmenlerin Aile Katılımı Çalışmalarında İstenilen Başarının Elde} Edilmesi İçin Önerileri
a. Paydaşlara konferans ve seminerler düzenlenmeli
b. Öğretmen, veli toplantılarında aile katılımının önemini anlatmalı
c. Öğretmen, okul müdürü ve diğer yöneticilerle işbirliği yapmalı
d. Öğretmen aile katılımı çalışmalarına/etkinliklerine daha fazla yer vermeli
e. Öğretmen kılavuz kitaplarında aile katılımı çalışmalarına/etkinliklerine yer verilmeli
f. Öğretmen aile ile sağlıklı iletişim kurmalı
g. Aile katılımı etkinlikleri planlanmalı
h. Okul yöneticileri ve MEB aile katılımı çalışmalarına/etkinliklerine destek vermeli
i. Okulların fiziki alt yapısı iyileştirilmeli
j. Aile katılımı etkinliklerine yönelik ailelere dönüt verilmeli
k. Öğretmen aile katılımı konusunda donanımlı olmalı
1. Cumartesi günleri aile katılımı çalışmaları yapılmalı

Çizelge 8. Sınıf Öğretmenlerin Aile Katılımı Çalışmalarında İstenilen Başarının Elde Edilmesi İçin Önerileri

Çizelgel 8'te görüldüğü gibi, aile katılımı çalışmalarında istenilen başarının elde edilmesi için yapılması gerekenler konusunda kendisiyle görüşülen öğretmenler "Paydaşlara konferans ve seminerler düzenlenmeli", "Öğretmen, veli toplantılarında aile katılımının önemini anlatmalı", "Öğretmen, okul müdürü ve diğer yöneticilerle işbirliği yapmalı", "Öğretmen, aile katılımı çalışmalarına daha fazla yer vermeli", "Öğretmen aile katılımı çalışmalarına daha fazla yer vermeli" ve "Öğretmen kılavuz kitaplarında aile katılımı çalışmalarına yer verilmeli” biçiminde görüş bildirmiştir. Yine, kendisiyle görüşülen öğretmenler "Öğretmen, aile ile sağlıklı iletişim kurmalı", "Aile katılımı etkinlikleri planlanmalı", "Okul yöneticileri ve MEB aile katılımı çalışmalarına destek 
vermeli", "Okulların fiziki alt yapısı iyileştirilmeli", "Aile katılımı etkinliklerine yönelik ailelere dönüt verilmeli", "Öğretmen aile katılımı konusunda donanımlı olmalı" ve "Cumartesi günleri aile katılımı çalı̧̧maları yapılmalı" biçiminde aile katılımı çalışmalarında istenilen başarının elde edilmesi için yapılması gerekenler konusunda görüş bildirmiştir.

Öğretmenlerden Ö6 "Yani onlarl mutlaka almak gerekir, onlara eğitimler vermek gerekir. İște az önce iște ailenin eğitimdeki önemi üzerine mutlaka sı sı iște çocukların zihinsel, fiziksel, duygusal özellikleri konusunda eğitimler verilirse aileler daha çok okulu sever, okula daha çok gelirler, eğitimin kalitesi artar yani kesinlikle buna inanıyoruz. Ailelerin, eğitimi çocukla ilgili olmalıdır.", Ö21, "Bunun için neler yapllmalıdır? Öncelikle toplantılarda rehberlik servislerinden ana sinufindan başlayarak şimdi anaokulları da aslinda o şekilde düşünebiliriz daha fazla bir şekilde veliyi yönlendirmeli öncelikle ilkokula ya da ikinci kademeye hazırlayacak şekilde yönlendirmeli ve yönlendirdiği takdirde biz birtakım şeyler elde edebiliriz. Biz zaten diyorum ya ilk toplantıya girdiğim zaman birinci sinıfi alıp da ilk toplantıya girdiğim zaman o veliye, tüm velime biz arkadaş işte şu kadar kişilik bir aileyiz, bundan sonra şu çalışmaları yapacaz. Buna hazır mısinız o şeyi desteği almam gerekiyor. Bunu öncelikle veliye kabul ettirmek gerekiyor o şekilde yaklaşlyorum olaya." ve Ö4 "Bu sirf

ögretmenle değil okul müdürü, müdür yardımclsl, diğer yöneticilerle beraber daha iyi ön hazırlı yapılması gerekir düşüncesindeyim. " biçiminde görüş bildirerek aile katılımı çalışmalarında istenilen başarının elde edilmesi için paydaşlara konferans ve seminerler düzenlenmesi gerektiğini, veli toplantılarında öğretmenin bu konunun önemini ailelere anlatması ve okul müdürü ve diğer yöneticilerle işbirliği yapmaları gerektiğini belirtmişlerdir.

Öğretmenlerden Ö33 "Şimdi istenilen başarıyı sağlamak için öncelikle veliyle iletişim iyi diyorum ama slnırl aradaki sinır da biraklyorum her zaman. Samimiyimdir ama samimiyette hiçbir zaman ileriye gitmem, gidilmesine de izin vermem. En başında kesin kurallarımı da koymuşumdur mesela. Velilerin ilk veli toplantısında ya da ikinci veli toplantımda sinıfimda uyulması gereken kuralları, velilerin uyması gereken kuralları açılk açık söylüyorum. Bunlar yapılırsa mutlak güzel bir iletişim kurulur.", Ö14 "En birinci olarak planlama yapılmalıdır.", Ö26 "Tabii bunda velilerin sorumlu olduğ $u$ kadar en önemli sorumluluk okul- öğretmen, Milli Eğitim Bakanlı̆̆ bunlara destek olması gerekir. Okullarımız fiziki yeterliliklerin artırllması gerekiyor.", Ö30 "Katıldl, velilere onure edici, mutlu edici geri dönütlerin verilmesi gerektiğini düşünüyorum ben.”, Ö34 “ístenilen başarıyı kazanmak için önce öğretmenin çok iyi donanımlı olması gerekiyor, veliyi nasll yönlendireceğini iyi bilmesi gerekiyor, öğrenciye nasıl yaklaşması gerektiğini iyi bilmesi gerekiyor, her veliye iyi yön vermek gerekiyor, 
velilerin sosyal ve psikolojik durumların çok iyi taniyarak onları yönlendirmekte ögretmenlere çok büyük görevler düşmekte, ögretmen çok iyi bir planlama yapmakta, velileri çok iyi yönlendirmek zorunda, öğrencileri çok iyi yönlendirmek zorunda ve iyi bir çalı̧̧ma sonucunda da istenilen başarı săglanmış oluyor." ve Ö35 "Bir defa çalışan veliler bizim için büyük bir sorun. Onların gelmesini de çok istiyoruz. Cumartesi günleri bu tür çalışmaları okulda yapabilirsek, onlar da katılabilirler." biçiminde görüş bildirerek aile katılımı çalışmalarında istenilen başarının elde edilmesi için öğretmenin aile ile iletişim kurması, planlama yapılması, okul yöneticilerin ve Milli Eğitim Bakanlı̆̆ı'nın bu tür çalışmaları desteklemesi ve okulların fiziki yapılarının iyileştirilmesi, aile katılımı çalışmalarına katılan ailelere dönüt verilmesi, öğretmenin bu konuda donanımlı olması ve cumartesi günleri okulda bu tür etkinliklerin yapılması gerektiğini belirtmişlerdir.

\section{Sonuç, Tartışma ve Öneriler}

Öğretmenlerin, aile katılımı ve Hayat Bilgisi dersi kapsamında uyguladıkları aile katılımı çalışmalarına ilişkin görüşlerinden elde edilen bulgular ve bulgular doğrultusunda ortaya çıkan sonuçlar şöyle özetlenebilir:

- Öğretmenler, aile katılımını öncelikle ailenin çocuğun eğitim sürecine katılması olarak tanımlamışlardır. Ayrıca öğretmenler aile katılımını; ailenin çocuğuna destek olması, ailenin okul içinde ya da dışında yapılan etkinliklere katılması, ailenin okul ile işbirliği içinde olması, ailenin çocuğunu izlemesi, ailenin çocuğu ile ilgilenmesi ve zaman geçirmesi, ailenin okulda öğrenilen konuları yaşama geçirmesi, eğitimin bir boyutunu oluşturması ve topluma hizmet olarak tanımlamışlardır.

- Öğretmenler, Hayat Bilgisi dersi kapsamında düzenledikleri aile katılımı çalışmaları olarak öncelikle aileleri okuldaki sosyal etkinliklere davet ettiklerini ve gerektiğinde yardım aldıklarını belirtmişlerdir. Bunun yanı sıra aileleri sınıf etkinliklerine kattıklarını, çocuğa ailesiyle birlikte yapacağı etkinlikler verdiklerini, aileleri bilgilendirmek amacı ile toplantılar yaptıklarını, aile ziyaretleri gerçekleştirdiklerini ve ailelere anket uyguladıklarını belirtmişlerdir.

- Öğretmenler, aile katılımı çalışmalarının 1. sınıfta daha yoğun olmak üzere 2. ve 3. sınıflarda da uyguladıklarını belirtmişlerdir. Yine, öğretmenler aile katılımı çalışmalarının her sınıf düzeyinde olabileceğini, ayrıca aile katılımının öğretmene de bağlı olduğunu ifade etmişlerdir.

- Öğretmenler, aile katılımı çalışmalarını uygularken planlama yaptıklarını, aileleri bilgilendirdiklerini ve uyguladıklarını belirtmişlerdir. Kimi öğretmenler aileleri bilgilendirerek gönüllü aileleri belirlediklerini, planlama ve iş bölümü yaptıklarını ve uyguladıklarını belirtirken, kimi öğretmenler de aile katılımı çalışmalarını yıllık planda belirttiklerini ve resmi izin aldıklarını ifade etmişlerdir. Kimi öğretmenler, 
ise planlama yaparak aileleri ikna ettiklerini, uyguladıklarını ve aile katılımı çalışmalarını değerlendirdiklerini belirtmişlerdir.

- Öğretmenler aile katılımı çalışmalarının; öğrencilerin öğrenmelerini olumlu yönde etkilediğini, başarılarını, derse karşı ilgilerini ve öz güvenlerini arttırdığını, öğrencilerin ailesiyle birlikte bir şeyler yapmaktan mutlu olmalarını ve ailelerinin yanında kendilerini daha güvende hissetmelerini sağladığını belirtmişlerdir. Yine, öğretmenler aile katılımı çalışmalarının öğrencilerde sorumluluk bilinci geliştirdiğini, öğrencilerin derste daha etkin olmalarını sağladığını, öğrencilerin motivasyonunu arttırdığını, eğitime bakış açılarını olumlu yönde etkilediğini, öğrencilerin sosyal becerilerini geliştirdiğini, aile arası iletişimi arttırdı̆̆ını, açıklamışlardır. Ayrıca, öğretmenler aile katılımı çalışmalarının öğrencilerin öz değerlendirme yapabilmelerini, aile ve okul arasındaki ilişkiyi görmelerini, ailesiyle birlikte kaliteli zaman geçirmelerini, yaptı̆̆ artmasını, öğrencilerin kaynaklara daha kolay ulaşmalarını sağladığını açıklamışlardır. Öğretmenler, aile katılımı çalışmalarının öğrencilerin okulda öğrendikleri ile evde öğrendikleri arasında paralellik kurmasını ve derse hazırlıklı gelmelerini sağladığını da ifade etmişlerdir.

- Öğretmenler, öncelikle aile katılımı çalışmalarının öğretmenlerin işlerini kolaylaştırdığını belirtmişlerdir. Bunun yanı sıra, aile katılımı çalışmalarının öğretmenlerin öğrencinin ailesini ve öğrenciyi tanımasını, öğretmenlerle aile arasında iletişimi geliştirdiğini ifade etmişlerdir. Yine öğretmenler, aile katılımı çalışmalarının öğretmenleri mutlu ettiğini, öğretmenlere destek sağladığını, öğretmen-aile-okul işbirliğini güçlendirdiğini, öğretmenlerin çalışmalarını denetlenmesine olanak verdiğini belirtmişlerdir.

- Öğretmenler, aile katılımı çalışmalarının ailelere katkıları konusunda, ailelerin çocuklarını sınıf içinde gözlemleyebildiklerini, mutlu olduklarını, okulda/sınıfta yapılan çalışmalara yönelik bilgi sahibi olduklarını, çocuklarını tanıdıklarını, çocuğun eğitimi konusunda bilinçlendiklerini, çocuklarının eğitim-öğretimindeki önemini anlamalarını sağladığını, diğer ailelerle iletişim kurduklarını ve çocukları ile zaman geçirdiklerini belirtmişlerdir. Yine, öğretmenler aile katılımı çalışmalarının ailelerin; sınav kaygısından kurtulmalarına, öğrenmede bireysel farklılıkları fark etmelerine, yeni programlar hakkında bilgi sahibi olmalarına öğretmenle iletişim halinde olmalarına, öğretmene yönelik olumlu tutum geliştirmelerine ve öğretmeni değerlendirebilmelerine olanak verdiğini ifade etmişlerdir. 
- Öğretmenler, aile katılımı çalışmalarında karşılaşılan zorlukları; ailelerin aile katılımı çalışmalarına katılmak istememesi, öğrencilere verilen ödevlerin aileler tarafından yapılması, ailelerin çalışmaları nedeniyle zaman ayıramaması, ekonomik bakımdan olanaklarının yetersiz olması biçiminde belirtmişlerdir. Yine, okulun fiziki ortamının uygun olmaması, ailelerin öğretmene yönelik olumsuz tutum sergilemesi, öğrencinin sınıfta ailesini görünce olumsuz davranışlar sergilemesi, anne-babanın eğitim düzeylerinin düşük olması, ailelerin aşırı ilgili olması, aile katılımı çalışmalarının öğretmeni yorması, ailelerin çocuklarının okuldaki öğrenmelerini evde desteklememesi, öğrenci sayısının fazla olması, ailelerin sorumluluğu öğretmene bırakması ve parçalanmış ailelerin olması biçiminde açiklamışlardır.

- Öğretmenlerin, aile katılımı çalışmalarında istenilen başarının elde edilmesi için paydaşlara aile katılımı bağlamında gereksinim duydukları konularda konferans ve seminerler düzenlenmesi, öğretmenin veli toplantılarında aile katılımının önemini ailelere anlatması, öğretmenin, okul müdürü ve diğer yöneticilerle birlikte işbirliği yapması, öğretmenin aile katılımı çalışmalarına daha fazla yer vermesi, öğretmen kılavuz kitaplarında aile katılımı çalışmalarına yer verilmesi biçiminde öneriler de bulunmuşlardır. Yine, aile katılımı çalışmalarında istenilen başarının elde edilmesi konusuna ilişkin olarak öğretmenin aile ile iletişim kurması, aile katılımı etkinliklerin planlanması, okul yöneticilerin ve MEB'in aile katılımı çalışmalarına destek vermesi, okulların fiziki alt yapısının iyileştirilmesi, ailelere katılımlarından dolayı ailelere dönüt verilmesi, cumartesi günleri aile katılımı çalışmaları yapılması gerektiğini ifade etmişlerdir.

Araştırma sonucunda öğretmenlerin Hayat Bilgisi dersi kapsamında aile katılımına yönelik çeşitli çalışmalar düzenledikleri belirlenmiştir. Bu etkinliklerin başında öğretmenlerin öğrencilere ailesi ile birlikte yapacağı ödevler vermesi gelmektedir. Nitekim Özdemir'in (2009) yaptı̆̆ı araştırmada, aileler aile katılımına yönelik en çok yürütülen etkinliğin ailelerin çocukları ile birlikte ödev yapması olduğunu belirtmişlerdir. Bu, Akkaya'nın (2007) ve Işsk'ın (2007) yaptıkları araştırmada öğretmenlerin okulöncesi kurumlarda da aile katılımına ilişkin çeşitli etkinlikler düzenledikleri bulgusuyla örtüşmektedir.

Araştırmada öğretmenler, aile katılımı çalışmalarının birinci sınıfta yoğun olduğunu belirtmişlerdir. Araştırmanın bu bulgusu, Can'nın (2008) yaptığı araştırmada çocuğun sınıf düzeyi yükseldikçe velilerin okulla etkileşimin azaldığı bulgusuyla ilişkilendirilebilir.

Araştırmada öğretmenler, aile katılımı çalışmalarının öğrencilerin başarılarını arttırdığını belirtmişlerdir. Araştırmanın bu bulgusu, Gül (2007), Çelenk (2003), Çelenk (2002), Barnard (2004), Fan ve Chen (2001) ve Jeynes (2003) yaptıkları araştırmalarda 
aile katılımı çalışmaların öğrenci başarısı üzerinde olumlu etkiye sahip olduğu bulgusuyla örtüşmektedir.

Araştırmada öğretmenler, aile katılımı çalışmalarının ailelere çocuklarını tanımasını, yeni program hakkında bilgi sahibi olmasını ve öğretmenle iletişim kurmasını sağladığını belirtmişlerdir. Araştırmanın bu bulguları ile Barge ve Loges'ın (2003) yaptıkları araştırmada aile katılımı çalışmaları ile öğretmen ile aile arasında olumlu iletişim kurulduğu bulgusu ve Kuzu'nun (2006) yaptığı araştırmada aile katılımı çalışmaların ailelerin anaokulu programı hakkında bilgi sahibi olmasını, çocuklarını daha iyi tanımalarına sağladığı bulgularıyla örtüşmektedir.

Araştırmada öğretmenler, aile katılımı çalışmalarının öğretmenlere öğrencilerin ailesini tanıma olanağı verdiğini ve kendilerini mutlu hissettiklerini belirtmişlerdir. Araştırmanın bu bulgusu, Akkaya'nın (2007) yaptığı araştırmada aile katılımı çalışmaların öğretmenlerin ve ailelerin aile katılımı çalışmalarına katılmaktan dolayı mutlu oldukları bulgusuyla örtüşmektedir.

Araştırmada öğretmenler, aile katılımı çalı̧̧alarını uygularken; ailelerin etkinliklere katılmak istememesi, ailelerin etkinliklere zaman ayıramaması, ailelerin ekonomik bakımdan olanaklarının yetersiz olması, eğitim düzeyinin düşük olması ve parçalanmış ailelerin olması gibi zorluklarla karşılaşıtılarını belirtmişlerdir. Nitekim, Özdemir'in (2009) yaptığı araştırmada ailelerin zaman sorunundan dolayı aile katılımı çalışmalarına katılmadıkları bulgusuna ulaşılmıştır. Yine, Aydoğan (2007) ve Yaylacı'nın (1999) yaptıkları araştırmada aile katılımını engelleyen etmenler arasında zaman problemi ve ekonomik problemlerden söz edilmektedir. Günkan (2007), yaptığı araştırmada velilerin görüşleri doğrultusunda ekonomik sıkıntılar ve ailenin eğitim düzeyinin düşük olmasının ailelerin eğitime katılım düzeyini düşürdüğü bulgusuna ulaşmıştır. Akkaya (2007) ise yaptığı araştırmada öğretmenlerin, anne-babası ayrı olan çocukların aile katılımı çalışmalarını olumsuz etkilediğini belirttikleri bulgusunu ortaya koymuştur.

Araştırmada, öğretmenler aile katılımı çalışmalarında istenilen başarının elde edilmesi için ailelere seminerler verilmesi gerektiğini belirtmişlerdir. Araştırmanın bu bulgusu, Sadık ve Doğanay'ın (2008) yaptıkları araştırmada, öğretmenlerin ailelerin bilinçlendirilmesi gerektiğini düşündükleri bulgusuyla örtüşmektedir. Araştırmada, öğretmenlerle yapılan görüşmeler sonucunda, öğretmenlerin aile katılımını öncelikle ailenin çocuğun eğitim sürecine katılması olarak tanımladıkları görülmüştür. Ayrıca öğretmenler aile katılımını; ailenin çocuğuna destek olması, ailenin okulda içinde ya da dışında yapılan etkinliklere katılması, ailenin okul ile işbirliği içinde olması, ailenin çocuğunu izlemesi, ailenin çocuğu ile ilgilenmesi ve zaman geçirmesi, okul ile işbirliği içinde olması, ailenin okulda öğrenilen konuları yaşama geçirmesi, eğitimin bir 
boyutunu oluşturması ve topluma hizmet olarak tanımlamışlardır. Aynı zamanda öğretmenler, aile katılımı çalışmalarını uygularken planlama yaptıklarını, aileleri bilgilendirdiklerini ve uyguladıklarını belirtmişlerdir. Bunun yanı sıra, öğretmenler aileleri bilgilendirerek gönüllü aileleri belirlediklerini, planlama ve iş bölümü yaptıklarını ve uyguladıklarını belirtmişlerdir. Yine, öğretmenler aile katılımı çalışmalarını yıllık planda belirttiklerini ve resmi izin aldıklarını ifade etmişlerdir. Ayrıca, planlama yaparak aileleri ikna ettiklerini, uyguladıklarını ve aile katılımı çalışmalarını değerlendirdiklerini de belirtmişlerdir. Bu kapsamda uygulamaya ve ileri araştırmalara yönelik şu önerilerde bulunabilir:

- Aile katılımı çalışmaları konusunda paydaşlara konferans ve seminerler düzenlenmelidir.

- Öğretmenlerin aile katılımı çalışmaların uygulayabilmesi için Hayat Bilgisi dersi öğretim programında aile katılımı çalışmalarına ayrı bir bölüm olarak yer verilmelidir.

- Öğretmenler, veli toplantılarında ailelere aile katılımının önemini anlatmalıdır.

- Öğretmenler aile katılımı konusunda okul müdürü ve diğer yöneticilerle işbirliği yapmalıdir.

- Aile katılımı çalışmalarının diğer derslerdeki uygulamalarına yönelik de çalışmalar yapılabilir.

- Aile katılımı çalışmalarının öğrencilerin akademik başarısı üzerindeki etkisini belirlemeye yönelik deneysel çalışmalar yapılabilir.

- Aile katılımı çalışmalarının öğretmenler ve veliler üzerindeki etkisini incelemek için deneysel çalışmalar yapılabilir.

- Aile katılımı çalışmalarına yönelik eylem araştırmaları yapılabilir.

\section{Kaynakça}

Akkaya M. (2007). Öğretmenlerin ve velilerin okulöncesi eğitim kurumlarında uygulanan aile katılımı çalışmalarına ilişskin görüşleri. Yayınlanmamış yüksek lisans tezi, Eskişehir, Anadolu Üniversitesi.

Anderson K. J. and Mike, M. K. (2007). Parent involvement in education toward an understanding of parents' decision making. The Journal of Educational Research, 100 (5), 311-323. 


\section{Parent Involvement Studies In Social Studies Course In Primary Education}

Binbaşıŏ̆lu, C. (2003). Hayat bilgisi öğretimi. Ankara: Nobel Yayın Dağıtım.

Bogdan, R. C. ve Biklen, S. K. (2006). Qualitative research for education an introduction to theory and methods. USA: Pearson International Edition.

Can, B. (2008). Illköğretim programının uygulanmasında veli katılımı düzeyi. Yayınlanmamış yüksek lisans tezi, Eskişehir, Eskişehir Osmangazi Üniversitesi.

Cavkaytar, A. (2008). Okul-aile işbirliğini geliştirme etkinlikleri. E. A. Küçükyılmaz

(Ed.). Okul, aile ve çevre iş birliği içinde (ss.77-95). Eskişehir: Anadolu Üniversitesi Açıöğretim Fakültesi Yayınları.

Chen, G. (2008). Parental involvement is key to student success. http://www.publicschoolreview.com/articles/12 adresinden $10 \quad$ Kasim 2009 tarihinde edinilmiştir.

Çelenk, S. (2002). İlkokuma-yazma öğretiminde karşılaşılan sorunlara ilişkin öğretmen görüşleri. Illköğretim Online, 1 (2). http:/ www.ilkogretim.online.org.tradresinden 10 Kasım 2008 tarihinde elde edilmiştir.

Çelenk, S. (2003). Okul-aile işbirliği ile okuduğunu anlama başarısı arasındaki ilişki. Hacettepe Üniversitesi Ĕ̈itim Fakültesi Dergisi, 24, 33-39.

Çilenti, K. (1988). Özel ögrretim yöntemleri. Eskişehir: Anadolu Üniversitesi Açıköğretim Fakültesi Yayınları.

Deveci, H. (2008). Hayat bilgisi dersinin tanımı, kapsamı ve ilköğretim programındaki yeri. Ş. Yaşar (Ed.). Hayat bilgisi ve sosyal bilgiler öğretimi içinde (ss.1-19). Eskişehir: Anadolu Üniversitesi Açıköğretim Fakültesi Yayınları.

Deveci, H. (2008). Hayat bilgisi dersinin tanımı, kapsamı ve ilköğretim programındaki yeri. Ş. Yaşar (Ed.). Hayat bilgisi ve sosyal bilgiler öğretimi içinde (ss.1-19). Eskişehir: Anadolu Üniversitesi Açıköğretim Fakültesi Yayınları.

Epstein J. L. (2001). School, family and commuity partnerships. ABD: Westview Press.

Fan, X. and Chen, M. (2001). Parental involvement and students' acaemic achievement: A meta-analysis. Educational Pshchology Review, 13 (1), 1-22.

Grolnick, S. W. and Slowiaezek, L. M. (1994). Parents' involvement in children'sschooling: a multidimensional conceptualization and motivational moel. Child Development, 65, 237-252. 
Gül, E. (2007). Eğitimde çocuk başarısı için okul-aile işbirliği. Yayınlanmamış yüksek lisans tezi, İstanbul, Yeditepe Üniversitesi.

Gültekin, M. (2004). Öğretme-öğrenme sürecinde yeni yaklaşımlar. Anadolu Üniversitesi Ĕ̈itim Fakültesi Dergisi, 14(1), 25-51.

Işık, H. (2007). Okulöncesi eğitim kurumlarında gerçekleştirilen okul-aile işbirliği çalışmalarının anne-baba görüşlerine dayalı olarak incelenmesi. Yayınlanmamış yüksek lisans tezi, Eskişehir, Anadolu Üniversitesi.

Jeynes, H. W. (2003). A meta-analysis the effects of parental involvement on minority children's academic achievement. Education and Urban Society, 35 (2), 202218.

Kuzu, N. (2006). Okulöncesi eğitim kurumlarında uygulanan aile katılımı çalışmalarının anne davranışları üzerindeki ve annelerin okulöncesi eğitime yönelik görüşlerine ilişkin etkisinin incelenmesi. Yayınlanmamış yüksek lisans tezi, Ankara, Gazi Üniversitesi.

Lim, Y. S. (2003). Parental involvement in education. G. Olsen and M. L. Fuller (Ed.). Home-school relations working successfully with parents and families in (ss.134157). USA: Pearson Education.

Mcmillan, J. H. (2004). Educational research: Fundamantals for the consumer. (Foruth Edition). USA: Pearson International Edition.

PTA (National Parent Teacher Association) (1998) .National standards for parent/familyinvolvementprograms.http://www.ptasonline.org/kspta/national_sta ndards.pdf adresinden 10 Kasım 2009 tarihinde edinilmiştir.

Sönmez, V. (2005). Hayat bilgisi ögrretimi ve sosyal bilgiler ögrretimi ögretmen kılavuzu. Ankara: Anı Yayıncılık.

Sözer, E. (1998). Sosyal bilgiler programının amaçları, ilkeleri ve temel özellikleri. G. Can (Ed.). Sosyal bilgiler öğretimi içinde (ss.15-39). Eskişehir: Anadolu Üniversitesi Açıköğretim Fakültesi Yayınları.

Stern, J. (2003). Involving parents. Newyork: Continuum.

Temel, F. (2007). Aile katılımı. Okulöncesi Eğitimi Sempozyumu içinde (ss.99-112). Antalya.

Yıldırım, A. ve Şimşek, H. (2010). Sosyal bilimlerde araştırma yöntemleri. Ankara: Seçkin Yayınları. 